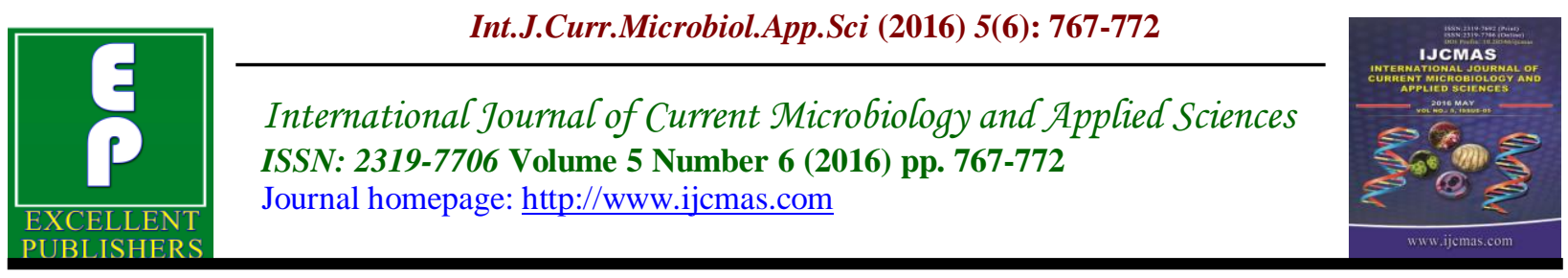

Original Research Article

http://dx.doi.org/10.20546/ijcmas.2016.506.083

\title{
Ethnobotanical Survey of Plants from the Caatinga with Possible Therapeutic Uses
}

\author{
Márcia Valéria Chagas Nogueira, Sandra Aparecida Bezerra de Lima Castro, Andréa \\ Monteiro de Amorim ${ }^{1}$, Robinson Magalhães Maia ${ }^{1}$ and Luis Cesar Maffei Sartini Paulillo* \\ Faculdade de Tecnologia e Ciências - FTC, Mestrado Profissional em Bioenergia. Av. \\ LuísViannaFilho, 8812, Pituaçu, Salvador, CEP 41.7411-490, BA- Brasil \\ *Corresponding author email id:
}

\begin{tabular}{|c|c|}
\hline & A B S T R A C T \\
\hline $\begin{array}{l}\text { Caatinga, } \\
\text { Riacho das Vacas, } \\
\text { medicinal plants, } \\
\text { etnobotanical } \\
\text { survey. }\end{array}$ & \multirow{3}{*}{$\begin{array}{l}\text { The ethnobotanical survey of Riacho das Vacas region aimed to analyze the } \\
\text { potential of flora in the region, seeking to understand the relation of the use of } \\
\text { plants by the native population with the medicinal use. The study aimed to } \\
\text { characterize the cultural aspects, identify the main categories of use of native } \\
\text { plants from the caatinga, regarding the therapeutic applications. Semi-structured } \\
\text { and structured interviews were carried out seeking information about the flora } \\
\text { and the way the community sorts the plants with their respectives uses. During } \\
\text { this period were interviewed } 47 \text { families of which were obtained information } \\
\text { like: popular names, occurrence, the used, preparation, dosage, indications and } \\
\text { prevalent notions of toxicities. }\end{array}$} \\
\hline Article Info & \\
\hline $\begin{array}{l}\text { Accepted: } \\
\text { 25 May } 2016 \\
\text { Available Online: } \\
\text { 10 June } 2016\end{array}$ & \\
\hline
\end{tabular}

\section{Introduction}

The Riacho das vacas community is closely linked to the uses of the plants for different purposes, such as mystical rituals, food, wood suppliers and especially for medicinal use because they are, in most cases, the only resource available to treat diseases in the community. The importance of ethnobotanical study in traditional rural populations, as recommended Casali (2000) and Prance (1991), due to the fact that they can recover the inheritance of knowledge that has been accumulated by the community and passed on to their descendants, but it is lost over time. According to the authors, the cultural revival and recording of traditional knowledge ensure their availability for future generations.

From the point of view of Casali (2000), more than two thirds of the species used are still collected directly from nature. Rescuing the local culture and protect the genetic patrimony of flora it is of great importance for the traditional communities, but it's critical awareness of biological and cultural wealth they have and the role it is to care and health maintenance.

The culture of a people that is based on human action is not limited in time, because: "Everyday life is presented as reality 
interpreted by men and subjectively endowed with sense to them, as forming a coherent whole" (Berger \& Luckmann, 2004). Thus, it is evident that the human being is the result of their work and their social relations may be inserted in a group that consider their values and become aware of the importance of crop species and transmission of values that must be preserved. Santos (1995), points out that every society develops its ways of solving problems and controlling diseases, as well as the perceptions of symptoms and the ways in which each disease is treated.

It is observed so that this practice is culturally passed from elderly people to younger, through observation and oral transmission and this requires an intense contact between the two (Coelho, 2000). Thus, it may be said that knowledge is accumulated as the years pass and elderly people have more knowledge than the younger ones.

As explained Diegues (2000), the women are historically holders of knowledge related to nature, as of course are more participating because of their more direct relationship with the environment. It can be said that the ethnobotanical inheritance of a society is dependent on vast forest area from which you can give richness of knowledge and possible therapeutic applications (Elizabetsky, 1987).

\section{Material and Methods}

\section{Study Area}

The study was conducted at the Riacho das Vacas community, located in the municipality of Caetité in the southwestern region of Bahia, in an area of approximately 560 hectares. It is the caatinga ecosystem with approximately 734,478 square kilometer area, according to the Ministry of the Environment-MMA (2008), characterized by low precipitation of rain, high temperatures, high solar radiation and low relative humidity.

The community is located 5 kilometers from the Nuclear Industry of Brazil (INB), 55 kilometers from Caetité and has 207 inhabitants, 88 men, 74 women and 45 children in a total of 47 families.

The ethnobotanical survey was conducted in upland areas, such as swiddens, gardens, farmyard, dense forest, also covering a conservation area of INB, occupying in total an area of approximately 50 hectares.

The community of Riacho das Vacas and the conservation area of INB along with the surrounding regions are practically in the area of dense arboreal caatinga and open arboreal (anthropic and crops for subsistence areas).

The highest temperatures occur during the month of October, with average temperatures of $22.6^{\circ} \mathrm{C}$ and minimum of $17.0^{\circ} \mathrm{C}$; the lowest temperatures are observed in July with an average temperature of $19.1^{\circ} \mathrm{C}$ and minimum of $13.7^{\circ} \mathrm{C}$.

According to climate typology developed by Koppen (1938), the climate is classified as Aw (f) - transition to Bsh (h), this is, transition from a hot and humid climate with dry season in winter, for the hot semiarid climate.

The precipitation in Caetité region is on average $600-800 \mathrm{~mm}$ of rain per year, with an average annual rainfall of $797.1 \mathrm{~mm} /$ year. Rainfall is concentrated in the summer and late spring, particularly in November, December, January and February. In this 
region the period of the winter is the one with the largest reduction in rainfall.

\section{Collection and Analysis of Information}

At first, a visit was undertaken in the community in order to know their cultural habits by monitoring with the social worker in the area.

For the analysis of flora was carried out botanical classification of the main species with therapeutic applications, as well as ethnobotanical survey undertaken between June and July 2012. There were semistructured interviews, objective information on the plants, such as: popular names, occurrence, used part, method of preparation, indications and dosages, as well as the prevalent diseases, plant toxicity notions, main risk factors to disease, among others.
And then were made herbarium for subsequent identification by botanical herbarium of UEFS- State University of Feira de Santana and EPAMIG- Agricultural Company of Minas Gerais., Main risk factors to disease, among others.

\section{Results and Discussion}

It was noted that $70 \%$ of those responsible for family support had farming as one way to survive by cultivating manioc, palm, banana, vegetables, sweet potatoes and typical fruitsof the region. The main economic activity until mid-2011 the region continued to be family agriculture (cotton, beans, vegetables and manioc), because of the drought today families survive basically from government social benefits.

Table.1 Classification and use of medicinal plants used by more Riacho das Vacas community of Caetité- BA.

\begin{tabular}{|c|c|c|c|c|c|c|}
\hline $\begin{array}{l}\text { Common } \\
\text { Name }\end{array}$ & ScientificName & O.U. ${ }^{1}$ & F.P. & T.P. & Purpose & Preparation \\
\hline $\begin{array}{c}\text { Água da } \\
\text { colônia ou } \\
\text { (catinga-de- } \\
\text { mulata) }\end{array}$ & $\begin{array}{l}\text { Tanacetum } \\
\text { vulgare } \mathrm{L} .\end{array}$ & Fo & $\mathrm{C}$ & I & $\begin{array}{l}\text { Calming and } \\
\text { dizziness }\end{array}$ & $\begin{array}{l}\text { Making tea and take it } \\
\text { daily. }\end{array}$ \\
\hline Alcachofra & $\begin{array}{l}\text { Cynara scolymus } \\
\text { L. }\end{array}$ & Fo & $\mathrm{C}$ & I & $\begin{array}{lr}\text { For } & \text { intestinal } \\
\text { problems } & \text { and to } \\
\text { reduce } & \text { the } \\
\text { menstrual } & \text { cycle, } \\
\text { headaches } & \text { and } \\
\text { dizziness. } & \end{array}$ & $\begin{array}{l}\text { Rub your hand and } \\
\text { smell leaves. Making } \\
\text { tea and take it daily. }\end{array}$ \\
\hline Alecrim & $\begin{array}{l}\text { Rosmarinus } \\
\text { officinalis L. }\end{array}$ & Fo & $\mathrm{C}$ & I & $\begin{array}{l}\text { Cough, } \\
\text { cardiovascular and } \\
\text { eye problems. }\end{array}$ & $\begin{array}{l}\text { The roasted and ground } \\
\text { leaves mixed with } \\
\text { nutmeg. The powder } \\
\text { used for inhalation in } \\
\text { cases of sinusitis, } \\
\text { influenza and nasal } \\
\text { congestion. }\end{array}$ \\
\hline
\end{tabular}


Int.J.Curr.Microbiol.App.Sci (2016) 5(6): 767-772

\begin{tabular}{|c|c|c|c|c|c|c|}
\hline Alfavaca & $\begin{array}{l}\text { Ocimum } \\
\text { gratissimumL. }\end{array}$ & Fo & $\mathrm{C}$ & I & Bronchitis and flu & $\begin{array}{l}\text { Making tea and take it } \\
3 \text { times a day. }\end{array}$ \\
\hline Anador & $\begin{array}{l}\text { Ecbolium } \\
\text { pectorale }\end{array}$ & Fo & $\mathrm{C}$ & I & Headache and fever & $\begin{array}{l}\text { Making tea and taken } \\
\text { during the period you } \\
\text { have fever and pain. }\end{array}$ \\
\hline Arruda & $\begin{array}{l}\text { Ruta graveolens } \\
\text { L. }\end{array}$ & Fo & $\mathrm{C}$ & I & $\begin{array}{l}\text { Swelling in the } \\
\text { body, gynecological } \\
\text { problems and } \\
\text { menstrual cramps. }\end{array}$ & $\begin{array}{l}\text { Making tea and take it } \\
3 \text { times a day and also } \\
\text { use this infusion to sitz } \\
\text { bath. }\end{array}$ \\
\hline Aspirina & $\begin{array}{l}\text { Althernanthera } \\
\text { brasiliana (L.) O. } \\
\text { Kientize }\end{array}$ & Fo & $\mathrm{C}$ & I & $\begin{array}{l}\text { Headache, flu and } \\
\text { fever }\end{array}$ & $\begin{array}{l}\text { Making tea and taken } \\
\text { during the period you } \\
\text { have fever and pain. }\end{array}$ \\
\hline Bambuzinho & Bambusa vulgaris & $\mathrm{C}$ & $\mathrm{C}$ & I & $\begin{array}{lr}\text { Gastritis, } & \text { renal } \\
\text { disorders, } & \text { urinary } \\
\text { tract infections. } & \end{array}$ & $\begin{array}{l}\text { Making tea and take it } \\
3 \text { times a day. }\end{array}$ \\
\hline Barbatimão & $\begin{array}{l}\text { Stryphnodendron } \\
\text { barbatiman } \mathrm{M} .\end{array}$ & Fo & $\mathrm{T}$ & $\mathrm{D}$ & Cicatrisant & $\begin{array}{l}\text { Do the tincture and } \\
\text { wash the wounds }\end{array}$ \\
\hline Boldo & $\begin{array}{l}\text { Vernonia } \\
\text { candensata }\end{array}$ & Fo & $\mathrm{C}$ & I & Indigestion & $\begin{array}{l}\text { Kneading the leaves } \\
\text { and leave infusion for } \\
\text { two hours. Drink } \\
\text { itslowly all day }\end{array}$ \\
\hline Capim santo & $\begin{array}{l}\text { Cymbopogon } \\
\text { citratus (D.C.) } \\
\text { Stapf. }\end{array}$ & Fo & $\mathrm{C}$ & $\mathrm{I}$ & $\begin{array}{l}\text { Calming, } \\
\text { abdominal pain and } \\
\text { fever }\end{array}$ & $\begin{array}{l}\text { Making tea and take it } \\
\text { daily. }\end{array}$ \\
\hline Erva cidreira & $\begin{array}{l}\text { Melissa officinalis } \\
\text { L. }\end{array}$ & Fo & $\mathrm{C}$ & I & Hypertension & $\begin{array}{l}\text { Making tea and take it } \\
\text { daily. }\end{array}$ \\
\hline Erva doce & $\begin{array}{l}\text { Pimpinella } \\
\text { anisum }\end{array}$ & Fo & $\mathrm{C}$ & $\mathrm{I}$ & $\begin{array}{l}\text { Flatulenceand } \\
\text { abdominal pain }\end{array}$ & $\begin{array}{l}\text { Making tea and take it } \\
\text { daily. }\end{array}$ \\
\hline Folha santa & $\begin{array}{l}\text { Aloysia } \\
\text { gratissima }\end{array}$ & Fo & $\mathrm{C}$ & $\mathrm{O}$ & Earaches & $\begin{array}{l}\text { Place the leaves in a } \\
\text { pan and leave on low } \\
\text { heat to release a liquid. } \\
\text { Collecting the liquid } \\
\text { dripping it in the ear } \\
\text { three times a day. }\end{array}$ \\
\hline $\begin{array}{l}\text { Hortelã } \\
\text { graúda ou } \\
\text { Hortelã } \\
\text { pimenta }\end{array}$ & $\begin{array}{l}\text { Coleus } \\
\text { amboinicus }\end{array}$ & Fo & $\mathrm{C}$ & I & Intestinal cramps & $\begin{array}{l}\text { Making tea and take it } \\
3 \text { times a day. }\end{array}$ \\
\hline $\begin{array}{l}\text { Hortelã } \\
\text { miúda }\end{array}$ & $\begin{array}{l}\text { Menthax } \\
\text { villosaL. }\end{array}$ & Fo & $\mathrm{C}$ & I & $\begin{array}{ll}\text { Cold and } & \text { flu, } \\
\text { indigestion } & \text { and } \\
\text { fever. } & \end{array}$ & $\begin{array}{l}\text { Making tea and take it } \\
\text { daily. }\end{array}$ \\
\hline
\end{tabular}




\begin{tabular}{|c|c|c|c|c|c|c|}
\hline $\begin{array}{l}\text { Losna de } \\
\text { homem }\end{array}$ & $\begin{array}{l}\text { Artemísia } \\
\text { absinthium L. }\end{array}$ & Fo & C & I & Indigestion & $\begin{array}{l}\text { You can make tea or } \\
\text { put in cachaça, } \\
\text { (Brazilian alcoholic } \\
\text { beverage) and drink } \\
\text { slowly. }\end{array}$ \\
\hline $\begin{array}{l}\text { Picão ou } \\
\text { carrapicho } \\
\text { de agulha }\end{array}$ & Bidens pilosa $\mathrm{L}$. & Fo & B & I & $\begin{array}{l}\text { Sitz bath for } \\
\text { problems of urinary } \\
\text { tract infection and } \\
\text { newborns with } \\
\text { jaundice. }\end{array}$ & $\begin{array}{l}\text { Boil the leaves to take } \\
\text { sitz bath or body wash. }\end{array}$ \\
\hline Poejo & $\begin{array}{l}\text { Mentha pulegium } \\
\text { L. }\end{array}$ & Fo & $\mathrm{C}$ & I & $\begin{array}{l}\text { Flu and children } \\
\text { being born teeth }\end{array}$ & $\begin{array}{l}\text { Making tea and take it } \\
\text { several times a day. }\end{array}$ \\
\hline Quitoco & $\begin{array}{l}\text { Pluche aquitoc } \\
\text { D.C. }\end{array}$ & Fo & $\mathrm{C}$ & I & Fluandcolds & $\begin{array}{l}\text { Making tea and take it } \\
\text { daily. }\end{array}$ \\
\hline Sabugueiro & $\begin{array}{l}\text { Sambucus } \\
\text { australis Cham. E } \\
\text { Schit. }\end{array}$ & Fo & $\mathrm{C}$ & I & $\begin{array}{l}\text { Flu and fever, } \\
\text { varicella } \\
\text { (chickenpox) }\end{array}$ & $\begin{array}{l}\text { Making tea for } \\
\text { drinking or bathing }\end{array}$ \\
\hline $\begin{array}{l}\text { Sete dores } \\
\text { ou Falso - } \\
\text { Boldo }\end{array}$ & $\begin{array}{l}\text { Coleus barbatus } \\
\text { Benth. }\end{array}$ & Fo & $\mathrm{c}$ & I & Indigestion & $\begin{array}{l}\text { Knead the leaves and } \\
\text { put in a glass of water. } \\
\text { Drink slowly until the } \\
\text { symptoms go away. }\end{array}$ \\
\hline
\end{tabular}

The studies conducted during the development of this study confirm the importance of environmental conservation and customs of the Riacho das vacas community. It tried to give answers to some questions about the conservation of flora and social inclusion, valuing the ethnobotanical aspects regarding the preservation of inherited knowledge and transmitted for generations.

It was considered that this study is very important in the search of popular knowledge about medicinal plants for therapeutic purposes that may attract and benefit a greater number of people, offering new parallel strategy to traditional medicine, especially for the new generations also will know and make use of the knowledge already used. As stated by Campos (1995) in the man-nature relationships, knowledge and practices reproduce at different levels of experience and all human society brings accumulation of information about the environment that surrounds it. It is considered that the incentives and cultivated values can be prioritized in the future to add new actions and knowledge to new projects that value popular practices information to be exploited with due respect to the local culture.

\section{Acknowledgements}

The authors would like to thank all those who contributed directly or indirectly to this work and in particular the Professional Masters in Bioenergy, College of Technology and Sciences (FTC-Salvador) for possible means to achieve them.

\section{References}

Berger PL, Luckmann T 2004- A construção social da realidade: 
tratado da sociologia do conhecimento. Lisboa: Dinalivro.

Campos MD 1995. Homem, saber e natureza. Campinas.

Casali VWD, Silva F 2000. Plantas Medicinais e Aromáticas: Póscolheita e Óleos Essenciais. VIÇOSA.

Coelho BMF 2000. Estudos para a conservação de recursos genéticos de plantas medicinais do entorno do Parque Estadual da Serra do Brigadeiro na Zona da Mata de Minas Gerais: uma abordagem etnobotânica.

Diegues AC 2000. Etnoconservação: novos rumos para a conservação da natureza. São Paulo: Hucitec.

Elisabetsky E 1987. Pesquisas em plantas medicinais. Ciência e Cultura 39:
(697- 702).

MMA - Ministério do Meio Ambiente. 2008. Mapa de Cobertura Vegetal dos Biomas Brasileiros.

Mota MGFC 1997 Plantas medicinais utilizadas por raizeiros: uma abordagem no contexto da saúde e doença. Cuiabá.

Pitman V 1996. Fitoterapia: As plantas medicinais e a saúde. Lisboa: Estampa.

Prance GT 1991. What is ethnobotany today? J. Ethnopharmacol. 32: (209216).

Santos MG, Dias AGP, Martins MM 1995. Conhecimento e uso da medicina alternativa entre alunos e professores de primeiro grau. Revista Saúde Pública, 29.

\section{How to cite this article:}

Márcia Valéria Chagas Nogueira, Sandra Aparecida Bezerra de Lima Castro, Andréa Monteiro de Amorim, Robinson Magalhães Maia, Luis Cesar Maffei Sartini Paulillo. 2016. Ethnobotanical Survey of Plants from the Caatinga with Possible Therapeutic Uses. Int.J.Curr.Microbiol.App.Sci. 5(6): 762-766. doi: http://dx.doi.org/10.20546/ijcmas.2016.506.083 